\title{
A Přídolí-Lochkovian conodont zonation in Sardinia and the Carnic Alps: implications for a global zonation scheme
}

\author{
CARLO CORRADINI \& MARIA G. CORRIGA
}

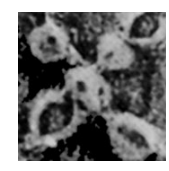

\begin{abstract}
The main conodont zonation schemes for the Přídolí and the Lochkovian presents some problems that make difficult their use in several geographical areas. Data from several sections in Sardinia and the Carnic Alps not only allow to built a regional zonation scheme for these areas, but also suggest possible solutions of global validity. In the Carnic Alps and Sardinia, the Př́dolí is subdivided into three zones: eosteinhornensis s.l., Lower and Upper detortus. The latter results after the subdivision of the former detortus Zone on the basis of the Last Appearance Datum of some coniform species (Dapsilodus obliquicostatus, Coryssognathus dubius and Panderodus recurvatus) that became extinct almost simultaneously in the latest Přídolí. Daps. obliquicostatus is chosen as the marker, being the most common and easily identifiable species. In the Lochkovian six zones are discriminated: hesperius, carlsi, transitans, eleanorae, trigonicus and pandora $\beta$. The hesperius Zone, which includes the postwoschmidti subzone in its upper part, is expanded to include most of the eurekaensis zone of the "global" scheme, because the marker Oz. eurekaensis is not present. The carlsi Zone corresponds to the upper part of the eurekaensis Zone and to the lower part of the former mid-Lochkovian delta Zone (= omoalpha Zone). The rest of the Middle Lochkovian is subdivided into the three zones (transitans, eleanorae and trigonicus) already proposed in Nevada and Spain, followed by the pandora $\beta$ Zone. All the zones are discussed and checked for their applicability in other palaeogeographical regions. - Key words: biostratigraphy, conodont zonation, Př́ídolí, Lochkovian, Carnic Alps, Sardinia.
\end{abstract}

Corradini, C. \& CORRIGA, M.G. 2012. A Přídolí-Lochkovian conodont zonation in Sardinia and the Carnic Alps: implications for a global zonation scheme. Bulletin of Geosciences 87(4), 635-650 (6 figures, 1 table). Czech Geological Survey, Prague. ISSN 1214-1119. Manuscript received July 26, 2011; accepted in revised form February 7, 2011; published online April 17, 2012; issued October 17, 2012.

Carlo Corradini (corresponding author), Dipartimento di Scienze Chimiche e Geologiche, Università di Cagliari, via Trentino 51, I-09127 Cagliari; corradin@ unica.it •Maria G. Corriga, Dipartimento di Scienze Chimiche e Geologiche, Università di Cagliari, via Trentino 51, I-09127 Cagliari; maria.corriga@ unica.it

This paper deals on a Přídolí-Lochkovian conodont zonation, based on sections in Sardinia and in the Carnic Alps, with the intention to make a step towards a standard zonation across the Silurian/Devonian boundary. The biozones defined in this paper are based on described and named taxa, that are easy to recognize unequivocally and have a wide geographic distribution, also outside the regions investigated in this paper. We choose markers in order that the zones should be widely recognized and applicable across geographic regions as broad as possible. Based on these principles, we avoided taxa with a small geographic diffusion, even if locally these forms can increase the biostratigraphic resolution of the scheme.

Data from Sardinia and the Carnic Alps were compared with data available in literature, not only in other North Gondwana regions (Bohemia, Spain, etc.) but also in other geographic areas (North America, Australia), in order to check the validity of the proposed scheme as a possible new global "standard" zonation. However, it is difficult to base correlations on literature only, because often the precise distribution of taxa is not given, and some paper are not adjourned with recent taxonomic novelties.

Before focusing on open problems in the main zonation schemes in use, it is necessary briefly summarizing the history of the Přídolí and Lochkovian conodont zonations.

\section{History of Př́ídolí and Lochkovian zonation schemes}

A separate discussion of the biozonation schemes of the $\mathrm{Si}$ lurian and the Lower Devonian is necessary because almost none covers the complete interval examined in this paper. In fact, almost all the schemes based on the Silurian only indicate the first Devonian Zone, and the Devonian schemes starts just above the system boundary. 


\begin{tabular}{|c|c|c|c|c|c|c|c|}
\hline 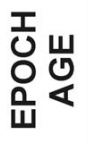 & $\begin{array}{l}\text { Walliser } \\
\text { (1964) }\end{array}$ & $\begin{array}{c}\text { Aldridge \& } \\
\text { Schoenlaub } \\
\text { (1989) }\end{array}$ & $\begin{array}{c}\text { Nowlan } \\
\text { (1995) }\end{array}$ & $\begin{array}{c}\text { Corradini } \\
\text { \& Serpagli } \\
\text { (1999) }\end{array}$ & $\begin{array}{l}\text { Ogg et al. } \\
\text { (2008) }\end{array}$ & $\begin{array}{c}\text { Corriga \& } \\
\text { Corradini } \\
(2009)\end{array}$ & $\begin{array}{c}\text { Cramer } \\
\text { et al. } \\
\text { (2011) }\end{array}$ \\
\hline \multirow{3}{*}{$\begin{array}{l}\text { 등 } \\
\text { 은 } \\
\text { 는 }\end{array}$} & \multirow{3}{*}{$\begin{array}{l}\text { "Oz. stein. } \\
\text { eosteinsis" }\end{array}$} & I. w. woschmidti & O. eost.-Ou. e. det. & elegans & elegans & \multirow[b]{2}{*}{ detortus } & \multirow[b]{2}{*}{ detortus } \\
\hline & & \multirow[b]{2}{*}{$\begin{array}{l}\text { O. rem. } \\
\text { eosteinsis }\end{array}$} & \multirow[b]{2}{*}{$\begin{array}{l}\text { remscheidensis } \\
\text { i. } \mathbf{Z} \text {. }\end{array}$} & detortus & detortus & & \\
\hline & & & & $\begin{array}{l}\text { remscheidensis } \\
\text { i. } Z \text {. }\end{array}$ & $\begin{array}{l}\text { remscheidensis } \\
\text { i. } Z \text {. }\end{array}$ & $\begin{array}{l}\text { eostein. s.l. } \\
\text { i. Z. }\end{array}$ & $\begin{array}{l}\text { eostein. s.l. } \\
\text { i. Z. }\end{array}$ \\
\hline نـ & "S. crispus" & O. crispa & crispa & crispa & crispa & crispa & crispa \\
\hline
\end{tabular}

Figure 1. Main conodont zonation schemes of the Př́idolí. L. means Ludlow.

\section{Přídolí}

The first conodont zonation for the Silurian was proposed by Walliser (1964), who based his scheme primarily on the Cellon Section (Carnic Alps, Austria), taking in account also some data from Bohemia and Spain. The author defined twelve successive appearance zones spanning the Silurian and the lowermost Devonian. The Přídolí was undivided (Fig. 1), being equivalent to the "Ozarkodina steinhornensis eosteinhornensis Zone". Several zones of the Walliser's scheme have been widely recognized, but the difficulties of applying the complete scheme in other parts of the world have led to the development of many local zonations. Also, since the seventies the nomenclature of conodonts have been greatly changed, because of recognition of multielement taxa.

Aldridge \& Schönlaub (1989), considering all the available data, provided a new scheme, which is a "step on the path to the development of a reference biozonation" (p. 275). The Přídolí is here subdivided into two parts: the great majority belongs to the "Ozarkodina steinhornensis eosteinhornensis Zone", whereas the very uppermost part was referred to the lower part of the "Icriodus woschmidti woschmidti Zone". It should be noted that the latter zone was identified also by Walliser (1964), but the First Appearence Datum of Icr. w. woschmidti was considered marking the base of the Lochkovian and therefore the latter zone to be of Devonian age.

The global zonation by Aldridge \& Schönlaub (1989) has been reported also in the Newsletter of the Subcommission on Silurian Stratigraphy (Silurian Times No. 1; 1993). Two years later, a new Conodont Global Zonation chart appeared (Silurian Times No. 3; Nowlan 1995), significantly different from the others, but never fully justified or discussed. The Přídolí zonation is not significantly different than the previous one, being subdivided into a "remscheidensis interval Zone" followed by a very thin "Ozarkodina eosteinhornensis-Oulodus elegans detortus Zone" in the uppermost part. Recognition of the latter zone is based on paper by Jeppsson $(1988,1989)$ on Silurian/Devonian boundary GSSP, the Klonk section in Bohemia. The I. w. woschmidti Zone was considered to be Devonian.

Corradini \& Serpagli $(1998,1999)$ proposed a new scheme, based on Sardinian data: the authors proved that the Sardinian conodont zonation is widely usable worldwide and claimed that it is "of practical use for Silurian biostratigraphy, and therefore more generally useful than extremely detailed schemes, sometimes based on not yet defined or endemic taxa" (Corradini \& Serpagli 1999, p. 270). Following these considerations, the same authors (Corradini \& Serpagli 2000) proposed their scheme as a Standard Silurian Conodont Zonation for the Wenlock-Přídolí time span. The Přídolí is subdivided into the same two zones of the Nowlan (1995) scheme, but the base of the detortus Zone was moved down within the Přídolí on the basis of new older recoveries of the marker Oulodus elegans detortus. This subdivision of the Přídolí was followed also by Ogg et al. (2008).

In the meantime, some taxonomical problems arose from the revision of some Ozarkodinids carried on by a few authors in the last few years (Murphy et al. 2004; Carls et al. 2005, 2007), who restricted the definition of the species remscheidensis and moved to genus Zieglerodina. In this new definition, Z. remscheidensis has its First Appearance Datum at the very top of the Přídolí (Corriga et al. 2009, Corradini \& Corriga 2010), but not in lower levels. Therefore, because it is not appropriate to name a zone by an absent taxon, Corriga \& Corradini (2009) renamed the former remscheidensis Zone as "Oz. eosteinhornensis s.l. interval Zone", without changing "the biostratigraphic meaning, since definition of the boundaries remains the same" (Corriga \& Corradini 2009, p. 160). Also, the base of the detortus Zone is moved again into a lower level, because of recoveries of the marker around the middle of the Přídolí in several geographical areas (Bohemia: Carls et al. 2007; 


\begin{tabular}{|c|c|c|c|c|c|c|}
\hline 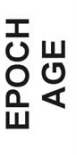 & $\begin{array}{c}\text { Klapper } \\
\text { (1977) } \\
\text { North America }\end{array}$ & $\begin{array}{c}\text { Ziegler } \\
\text { (1979) }\end{array}$ & $\begin{array}{c}\text { Weddige } \\
(\sim 1985) \\
\text { in Weddige (1996) }\end{array}$ & $\begin{array}{c}\text { Murphy \& } \\
\text { Valenzuela-Ríos } \\
\text { (1999) }\end{array}$ & $\begin{array}{l}\text { House \& } \\
\text { Gradstein } \\
(2004)\end{array}$ & $\begin{array}{l}\text { Ogg et al. } \\
(2008)\end{array}$ \\
\hline \multirow{6}{*}{ 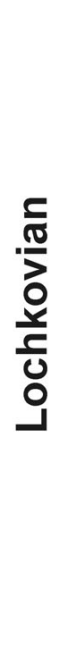 } & pesavis & \multirow[t]{3}{*}{ I. pesavis } & pesavis & pandora beta & pesavis & pesavis \\
\hline & \multirow{3}{*}{ Oz. sp. nov. D } & & \multirow{3}{*}{ delta } & trigonicus & \multirow{3}{*}{ delta } & \multirow{3}{*}{ delta } \\
\hline & & & & eleanorae & & \\
\hline & & Ancyrodelloides & & transitans & & \\
\hline & eurekaensis & postwoschmidti & eurekaensis & \multirow[t]{2}{*}{ eurekaensis } & \multirow{2}{*}{$\begin{array}{c}\text { postwoschmidti } \\
\text { woschmidti }\end{array}$} & eurekaensis \\
\hline & hesperius & woschmidti & $\begin{array}{c}\text { postwoschmidti } \\
\text { woschmidti }\end{array}$ & & & $\begin{array}{c}\text { postwoschmidti } \\
\text { woschmidti }\end{array}$ \\
\hline
\end{tabular}

Figure 2. Main conodont zonation schemes of the Lochkovian.

Carnic Alps: Corriga \& Corradini 2009; Frankenwald: Carls et al. 2007; Sardinia: Corriga et al. 2009).

Finally, Cramer et al. (2011) accept the Corriga \& Corradini (2009) proposal as the conodont zonation of the Přídolí into the more recent biostratigraphic and chronostratigraphic subdivision of the Silurian.

\section{Lochkovian}

If the history of conodont zonation of the Přídoli shows a linear evolution, with biozones usable world-wide, this is not the case for the Lochkovian (Fig. 2). In the seventies regional zonation schemes or successions of faunal units were proposed for various regions (i.e.: North America Klapper \& Murphy 1975, Klapper 1977; Podolia - Mashkova 1978), whereas conodont faunal sequences were described in other areas (i.e: Spain - Carls 1969, 1975; Carls \& Gandl 1969). Difficulties in correlating these areas were well evident (Klapper \& Ziegler 1979). Nevertheless, a compilation of conodont zones was done by Ziegler (1979, fig. 5), mainly based on Spanish and central European data.

In the eighties an attempt towards a global zonation was done ( $c f$. Weddige 1985 in Weddige 1996), mainly following the North American scheme. The lower and middle Lochkovian was subdivided into three zones: a woschmidti Zone, with the possible recognition of a postwoschmidti interval in its upper part, followed by the eurekaensis Zone and the delta Zone. This proposal, even if not widely ac- cepted because of problems in recognizing the woschmidti and the eurekaensis zones in several regions ( $c f$. Valenzuela-Ríos 1994a, Valenzuela-Ríos \& Murphy 1997, Murphy \& Valenzuela-Ríos 1999) was extensively used by conodont workers and in the more recent schemes (House \& Gradstein 2004, Ogg et al. 2008) there are no further variations for the lower Lochkovian.

Valenzuela-Ríos (1994a) working in the Spanish Central Pyrenees, recognized some intervals in the Lochkovian: his subdivision of the middle Lochkovian was the basis for further assessments by Valenzuela-Ríos \& Murphy (1997) and Murphy \& Valenzuela-Ríos (1999). These authors, on the basis of data from western United States and Spain, subdivided the delta Zone into four zones based on first appearances of species of genera Lanea and Ancyrodelloides: from the base L. omoalpha, Ad. transitans, L. eleanorae and Ad. trigonicus; the base of the upper Lochkovian would have been recognized by the First Appearance of Ozarkodina pandora morph $\beta$ (now Masaraella pandora morph $\beta$ ).

This proposal was not considered in the more recent zonations of the Lochkovian (House \& Gradstein 2004, Ogg et al. 2008), who repeat the previous schemes, without any comment. These schemes have been reported as "standard zonations", even if it is well known that they does not work in most of the world. This is even more surprising if we consider that these papers have been published under the auspices of the International Commission on Stratigraphy, and therefore many authors not aware of the Lower Devonian stratigraphy could consider valid. 
Table 1. Age of the sections studied in Sardinia and in the Carnic Alps.

\begin{tabular}{ll}
\hline Sections & Age \\
\hline SARDINIA & \\
Galemmu II & Lochkovian \\
Genna Arrela & Ludlow-Př́dolí \\
Genna Ciuerciu & Ludlow-Př́dolí \\
Mason Porcus & Př́dolí-Lochkovian \\
Monte Fruccas & Ludlow-Př́dolí \\
Perda S'Altari & Lochkovian \\
Ponte Monte Lora & Př́dolí \\
Punta Carroga & Př́idolí \\
San Basilio Fenugu & Ludlow-Lochkovian \\
Silius & Ludlow-Př́dolí \\
\hline CARNIC ALPS & \\
Casera La Valute & Ludlow-Př́dolí \\
Casera Pal Piccolo & Ludlow-Lochkovian \\
Cima Pizzul & Přídolí-Lochkovian \\
Costone Lambertenghi & Přídolí-Lochkovian \\
Cuestalta & Ludlow-Lochkovian \\
La Valute & Lochkovian \\
Monte Cocco II & Ludlow-Lochkovian \\
Monte Cocco III & Ludlow-Př́dolí \\
Rifugio Lambertenghi Fontana & Ludlow-Přídolí \\
Rifugio Lambertenghi Fontana III & Prowkovian-Lochkovian \\
\hline
\end{tabular}

\section{Open problems and goal of the paper}

In the conodont zonation schemes for the Přídolí and the Lochkovian there are still some open problems that should be solved before reaching a true global zonation. They can be summarized as follows:

- in the Př́idolí, recoveries of Oul. el. detortus in older levels expanded the detortus Zone, that now occupy more than half of the series. A subdivision of this interval into two zones is desirable.

- the eurekaensis Zone, widely used in Lochkovian schemes, is based on a taxon with a limited geographical distribution in the western North America. Its applicability in Europe and elsewhere is not possible.

- the subdivision of the delta zone into four zones, proposed by Murphy \& Valenzuela-Ríos (1999) for Spain and Nevada, should be checked in other palaeogeographic regions.

The main goal of this paper is to provide a regional zonation for the investigated areas. In addition we try to propose possible solutions to the problems highlighted above in order to make a step towards a global conodont zonation for the Prrídolí and the Lochkovian.

\section{Notes on taxonomy}

In the last few years a taxonomical revision of several late Silurian-Early Devonian conodont taxa was started by several authors. This work, mainly based on several genera of Ozarkodinids, has not been completed up to date, and probably a more detailed zonation shall be achieved when several Zieglerodina species, previously named Ozarkodina remscheidensis, will be described.

Discussion on taxonomy is not the goal of this paper, even more if it is based on the generic attribution of valid species. As example, the species "carlsi", was described by Boersma (1973) as Ozarkodina carlsi, and referred to the genus Ancyrodelloides by Klapper (1991). Recently, the species was attributed to genus Lanea by Slavík (2011) on the basis of the reconstruction of the apparatus. Basically we agree on this approach, but also the diagnoses of genera Lanea and Ancyrodelloides should be changed on the basis of a multielement apparatus, in order that the revision will be completed. However, independently from its generic attribution the species is valid and has the characteristics of a good index taxon, and therefore can be chosen as zonal marker.

\section{Material and geological settings}

The Přídolí-Lochkovian zonation proposed in this paper is based on several sections in the Carnic Alps and in Sardinia (Fig. 3, Table 1). During the middle Palaeozoic time these regions represented two terranes in the Northern Gondwana margin (Schönlaub 1997, Ferretti et al. 2009). Silurian and Lower Devonian sequences of these areas are among the better exposed in the whole North Gondwana and deposed in various depositional environments, from shallow platform to basinal.

\section{Carnic Alps}

Silurian and Lower Devonian deposits are irregularly distributed within the Carnic Alps, and range from shallow water bioclastic limestones to nautiloid-bearing limestones, interbedded shales and limestones to black graptolitic shales and cherts. The overall thickness does not exceed 60 meters. It is subdivided into four lithofacies associations representing different depths of deposition and hydrodynamic conditions (Wenzel 1997). The Wolayer-facies is characterised by proximal shelf sediments and the Bischofalm-facies by deep water deposits; the Plöcken-facies and the Findenig-facies represent intermediate facies associations. For a more detailed description refer to Histon \& Schönlaub (1999) and Schönlaub \& Histon (2000).

We have sections from the Wolayer, Plöcken and Findenig facies. From the Wolayer facies the Rifugio 

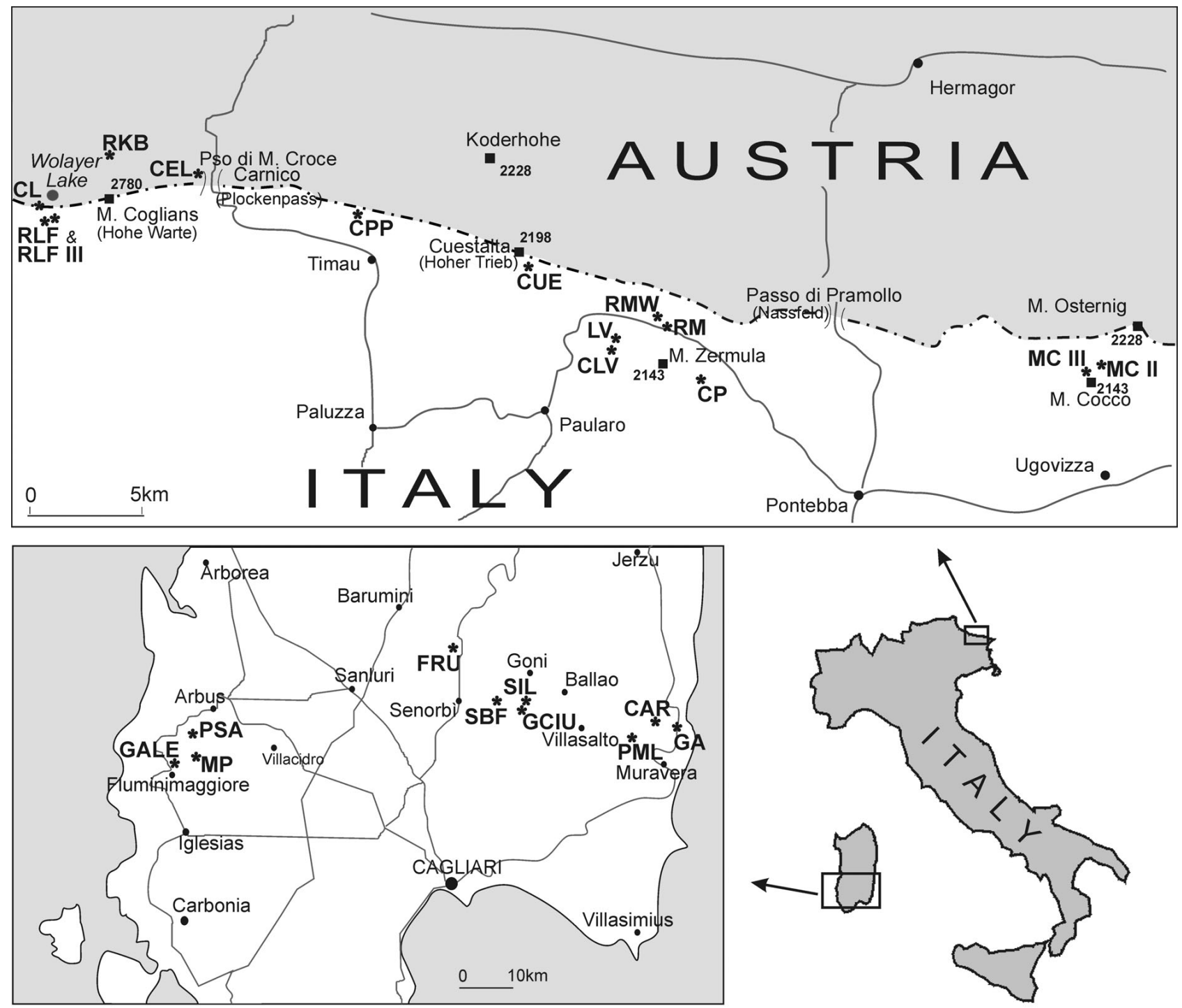

Figure 3. Location map of the studied sections. Locality abbreviations: Carnic Alps: CEL - Cellon; CL - Costone Lambertenghi; CLV - Casera La Valute; CP - Cima Pizzul; CPP - Casera Pal Piccolo; CUE - Cuestalta; LV - La Valute Cave; MC II - Monte Cocco II; MC III - Monte Cocco III; RKB - Rauchkofel Boden; RLF - Rifugio Lambertenghi Fontana; RLF III - Rifugio Lambertenghi Fontana III; RM - Rio Malinfier; RMW - Rio Malinfier West. Sardinia: CAR - Punta Carroga; FRU - Monte Fruccas; GA - Genna Arrela; GALE - Galemmu II; GCIU - Genna Ciuerciu; MP - Mason Porcus; PML - Ponte Monte Lora; PSA - Perda S'Altari; SBF - San Basilio Fenugu; SIL - Silius.

Lambertenghi Fontana and Rifugio Lambertenghi Fontana III sections (Corradini \& Corriga 2010) and the Costone Lambertenghi section (partly equivalent to the Seekopf Sockel section by Schönlaub 1980). From a facies similar to the Plöcken we studied the Monte Cocco II section (Corriga \& Corradini 2009), in the easten part of the Carnic Alps. From the Findenig facies the Rio Malinfier, Rio Malinfier West (Corriga 2011) and the La Valute section (Corriga et al. 2011). Furthermore, the first author had the chance to study the collections from the Silurian part of the Cellon Section (Walliser 1964) and from the Rauchkofel Boden (Schönlaub 1980) and other sections deposited at Göttingen University and in the
Geologisches Bundesandstalt in Wien. We included data from the Seewarte section (Suttner 2007) and several other sections still in study and/or unpublished in the Freikofel, Cuestalta/Hoher Trieb, Monte Zermula and Monte Cocco areas.

\section{Sardinia}

In Sardinia different sequences are exposed in the southeastern and in the southwestern part of the island: they remind to coeval sequences of Thuringia and Bohemia, respectively. For a complete description of the Silurian and 
Lower Devonian of Sardinia refer to Corradini et al. (2009c, and reference herein).

In SE Sardinia Přídolí rocks belong to the upper part of the Ockerkalk limestone, an argillaceous limestone with a blue-grey color weathering into ochre and a typical irregular flaser texture. The Lochkovian is represented by the "Upper graptolitic Shales", exclusively composed by alum slates. In this area conodonts are abundant only in the Ockerkalk, where several sections are known. For this paper we mainly considered the fauna from the sections where the Príidolí is better exposed: Silius (Barca et al. 1995, Corradini et al. 2009a), Genna Ciuerciu (Barca et al. 1995, Corradini et al. 2009b), Genna Arrela (Corradini \& Olivieri 1997, Corriga 2011); we also included data from the Ponte Monte Lora and the Monte Fruccas sections (Corradini \& Olivieri 1997), and San Basilio Fenugu (Corradini et al. 2001). We revised the conodont collections from these sections, stored in the Museum of Palaeontology of the University of Modena and Reggio Emilia.

In SW Sardinia the upper Silurian and Lower Devonian belong to the Fluminimaggiore and the Mason Porcus formations. The first is mainly represented by metric blocks and lenses of "Orthoceras" and graptolitic limestone interbedded with non calcareous pelites and shales; the latter consists of nodular and massive limestones alternating with compact dark siltstone and shales (Gnoli et al. 1990). Continuous sections with well preserved, abundant conodonts have been measured only from the latest Přídolí to the Lower Lochkovian: collections of the Mason Porcus (Gnoli et al. 1988, Olivieri \& Serpagli 1990) and Galemmu II (Mastandrea 1985, Corradini et al. 1998) sections have been restudied and updated on the basis of recent taxonomic revisions (Corriga 2011); data from Perda S'Altari section (Corriga 2007) have been considered, too.

\section{The Přídolí-Lochkovian conodont zonation in Sardinia and the Carnic Alps}

The conodont range of more than sixty taxa recovered from the investigated section is the base of the Prídolí-Lochkovian conodont zonation here presented. Nine conodont zones have been discriminated (Fig. 4). The stratigraphical distribution of taxa is shown in Fig. 5; index fossils and other taxa useful for stratigraphy are illustrated in Fig. 6.

All the biozone are here defined and discussed; lists of associated conodonts includes only taxa occurring in Sardinia and/or in the Carnic Alps. For further discussions see below.

\section{Eosteinhornensis s.l. interval Zone}

Lower limit. - Last occurrence of Ozarkodina crispa.
Upper limit. - First occurrence of Oulodus elegans detortus.

Associated conodonts. - Belodella anomalis Cooper, Belodella resima (Philip), Coryssognathus dubius (Rhodes), Dapsilodus obliquicostatus (Branson \& Mehl), Dvorakia amsdeni Barrick \& Klapper, Oulodus elegans elegans (Walliser), Oulodus siluricus (Branson \& Mehl), Ozarkodina confluens (Branson \& Mehl), Ozarkodina eosteinhornensis s.l. (Walliser), Ozarkodina snajdri (Walliser), Panderodus recurvatus (Rhodes), Panderodus unicostatus (Branson \& Mehl), Pseudooneotodus beckmanni (Bischoff \& Sannemann), Pseudooneotodus bicornis bicornis Drygant, Pseudooneotodus bicornis contiguus Corradini, Wurmiella excavata (Branson \& Mehl), Wurmiella alternata Corradini \& Corriga, Zieglerodina zellmeri Carls et al.

Remarks. - Naming this zone as "eosteinhornensis s.l. Zone" have been proposed by Corriga \& Corradini (2009) to substitute the "remscheidensis Zone" by Corradini \& Serpagli (1999). It was necessary after the taxonomical revision of late Silurian and Early Devonian Ozarkodinids (Murphy et al. 2004), that introduced a more restricted definition of Zieglerodina remscheidensis and shortened its range to younger levels. Ozarkodina eosteinhornensis s.1. is the more common taxon in this interval. The name variation did "not change the biostratigraphic meaning of the zone, since the definition of the boundaries remains the same" (Corriga \& Corradini 2009, p. 160). Oulodus elegans elegans could have been a good marker, too, but is less abundant than $O z$. eostenhornensis s.l. After a revision at species level of lower Přídolí ozarkodinids, it is possible that this interval can be further subdivided.

The base of this zone (LAD of $O z$. crispa) is the best conodont datum point to recognize the Ludlow/Přídolí boundary. Zieglerodina zellmeri is limited to this zone; Wurmiella alternata enters near the base of the zone and Dvorakia amsdeni in the upper part; Pseudooneotodus bic. bicornis became extinct in the lower part.

\section{Lower detortus Zone}

Lower limit. - First occurrence of Oulodus elegans detortus.

Upper limit. - Last occurrence of Dapsilodus obliquicostatus.

Associated conodonts. - Amydrotaxis sp., Belodella anomalis Cooper, Belodella coarctata Barrick \& Klapper, Belodella resima (Philip), Coryssognathus dubius (Rhodes), 


\begin{tabular}{|c|c|c|c|c|c|c|}
\hline & & $\begin{array}{c}\text { Murphy \& } \\
\text { Valenzuela-Ríos } \\
\text { (1999) }\end{array}$ & $\begin{array}{l}\text { Ogg et al. } \\
\text { (2008) }\end{array}$ & $\begin{array}{l}\text { Cramer et al. } \\
\quad(2011)\end{array}$ & THIS PAPER & \\
\hline \multirow{7}{*}{$\begin{array}{l}z \\
\mathbf{z} \\
\mathbf{z} \\
\mathbf{0} \\
\mathbf{u}\end{array}$} & \multirow{7}{*}{ 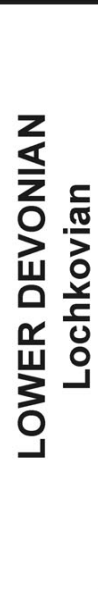 } & pandora beta & pesavis & & pandora $\beta$ & \multirow{2}{*}{ FAD M. pandora $\beta$} \\
\hline & & trigonicus & \multirow{4}{*}{ delta } & & trigonicus & \\
\hline & & eleanorae & & & eleanorae & \multirow{2}{*}{$\begin{array}{l}\text { FAD Ad. trigonicus } \\
\text { FAD Ad. eleanorae }\end{array}$} \\
\hline & & transitans & & & transitans & \\
\hline & & omoalpha & & & carlsi & \multirow{3}{*}{ FAD Ad. carlsi } \\
\hline & & eurekaensis & eurekaensis & & \multirow{2}{*}{$\begin{array}{l}\text { postwoschmidti } \\
\text { hesperius }\end{array}$} & \\
\hline & & hesperius & $\begin{array}{c}\text { postwoschmidti } \\
\text { woschmidti }\end{array}$ & & & \\
\hline \multirow{5}{*}{$\frac{z}{\frac{z}{\alpha}}$} & \multirow{4}{*}{$\begin{array}{l}\overline{\overrightarrow{0}} \\
\text { 员 } \\
\text { 金 }\end{array}$} & & \multirow{2}{*}{ elegans detortus } & \multirow{3}{*}{ detortus } & Upper detortus & \multirow{5}{*}{$\begin{array}{l}\text { LAD D. obliquicostatus } \\
\text { FAD Oul. el. detortus }\end{array}$} \\
\hline & & & & & \multirow{2}{*}{ Lower detortus } & \\
\hline & & & \multirow{2}{*}{$\begin{array}{l}\text { remscheidensis } \\
\text { i. Z. }\end{array}$} & & & \\
\hline & & & & $\begin{array}{l}\text { eosteinhornensis s.l. } \\
\text { i. Z. }\end{array}$ & $\begin{array}{l}\text { eosteinhornensis s.l. } \\
\text { i. Z. }\end{array}$ & \\
\hline & j & & crispa & crispa & crispa & \\
\hline
\end{tabular}

Figure 4. The Př́dolí-Lochkovian zonation scheme in Sardinia and the Carnic Alps with definition of the conodont zones. Selected previous schemes are reported for comparison. The column by Ogg et al. (2008), even if is based on old data and not usable in most of the world, is reported because is the more recent scheme and has been published as "standard" by the International Commission on Stratigraphy.

Dapsilodus obliquicostatus (Branson \& Mehl), Dvorakia amsdeni Barrick \& Klapper, Oulodus elegans elegans (Walliser), Oulodus elegans detortus (Walliser), Oulodus siluricus (Branson \& Mehl), Ozarkodina confluens (Branson \& Mehl), Ozarkodina eosteinhornensis s.l. (Walliser), Ozarkodina eosteinhornensis s.s. (Walliser), Ozarkodina planilingua Murphy \& Valenzuela-Ríos, Ozarkodina snajdri (Walliser), Panderodus recurvatus (Rhodes), Panderodus unicostatus (Branson \& Mehl), Pseudooneotodus beckmanni (Bischoff \& Sannemann), Pseudooneotodus bicornis contiguus Corradini, Wurmiella excavata (Branson \& Mehl), Wurmiella alternata Corradini \& Corriga, Zieglerodina ivoclupaci Carls et al., Zieglerodina klonkensis Carls et al.

Remarks. - This biozone is introduced herein. It corresponds to the lower part of the detortus Zone of previous schemes. In Sardinia and in the Carnic Alps a simultaneous last occurrence of some taxa (Dapsilodus obliquicostatus, Coryssognathus dubius and Panderodus recurvatus) in the upper Přídolí is documented: we chose to subdivide the detortus Zone on the basis of this extinction. As marker for the upper boundary we chose the Last Appearance Datum of Dapsilodus obliquicostatus, because is the more abun- dant and better documented species also in other part of the world. An extinction of several coniform species in the late Přídolí, including D. obliquicostatus, is documented also in North America (Jacobi et al. 2009). In the studied regions also Coryssognathus dubius could be a good marker, but choosing this species as marker would make more difficult long distance correlations, since the species is documented in the Přídolí only in Sardinia and the Carnic Alps (Corriga \& Corradini 2009), and in the Frankenwald (Carls et al. 2007).

In the upper part of the zone is present an horizon (grey shade in Fig. 5) characterized by Ozarkodina eosteinhornensis s.s.: the morphotype with a denticle or a small ridge above the basal cavity, similar to the specimen designed as holotype by Walliser (1964). These forms are useful in biostratigraphy, being present in the same narrow interval also in Bohemia and in the Frankenwald (Carls et al. 2007).

Zieglerodina ivochlupaci is exclusive of the central part of the zone, below the $O z$. eosteinhornensis s.s. horizon. Ozarkodina snajdri and Oulodus siluricus became extinct within this zone; $Z$. klonkensis, Oz. planilingua and Belodella coarctata have their first occurrences in the upper part. 


\section{Upper detortus Zone}

Lower limit. - Last occurrence of Dapsilodus obliquicostatus.

Upper limit. - First occurrence of Icriodus hesperius.

Associated conodonts. - Belodella anomalis Cooper, Belodella coarctata Barrick \& Klapper, Belodella resima (Philip), Dvorakia amsdeni Barrick \& Klapper, Oulodus elegans detortus (Walliser), Oulodus elegans elegans (Walliser), Ozarkodina confluens (Branson \& Mehl), Ozarkodina eosteinhornensis s.l. (Walliser), Ozarkodina planilingua Murphy \& Valenzuela-Ríos, Panderodus unicostatus (Branson \& Mehl), Pseudooneotodus beckmanni (Bischoff \& Sannemann), Pseudooneotodus bicornis contiguus Corradini, Wurmiella excavata (Branson \& Mehl), Zieglerodina eladioi (Valenzuela-Ríos), Zieglerodina klonkensis Carls et al., Zieglerodina remscheidensis (Ziegler).

Remarks. - This biozone is introduced herein. It corresponds to the upper part of the former detortus Zone. For discussion of the lower boundary see above (Remarks to the Lower detortus Zone). The upper boundary approximate the Silurian/Devonian boundary.

Even if the Upper detortus Zone probably represents a short time interval, some important datum points can be recognized: the LAD of Ozarkodina confluens occur in the upper part, immediately followed by the FAD of Zieglerodina remscheidensis and Z. eladioi.

\section{Hesperius Zone}

Lower limit. - First occurrence of Icriodus hesperius.

Upper limit. - First occurrence of Ancyrodelloides carlsi.

Associated conodonts. - Belodella anomalis Cooper, Belodella coarctata Barrick \& Klapper, Belodella resima (Philip), Dvorakia amsdeni Barrick \& Klapper, Icriodus hesperius Klapper \& Murphy, Icriodus postwoschmidti Mashkova, Icriodus woschmidti Ziegler, Lanea omoalpha Murphy \& Valenzuela-Ríos, Oulodus aclys Mawson, Oulodus elegans elegans (Walliser), Oulodus elegans detortus (Walliser), Oulodus greilingi hirpex Mawson, Ozarkodina eosteinhornensis s.1. (Walliser), Ozarkodina planilingua Murphy \& Valenzuela-Ríos, Panderodus unicostatus (Branson \& Mehl), Pandorinellina repetitor Carls \& Gandl, Pedavis biexoramus Murphy \& Matti, Pseudooneotodus beckmanni (Bischoff \& Sannemann), Sannemannia ichnusae Olivieri \& Serpagli, Wurmiella excavata (Branson \& Mehl), Zieglerodina eladioi (ValenzuelaRíos), Zieglerodina klonkensis Carls et al., Zieglerodina remscheidensis (Ziegler).
Remarks. - A basal Devonian zone defined by the first occurrence of species of Icriodus of the "woschmidti Group" was established from the beginning of Silurian/Devonian zonations (Walliser 1964), when all these species were named as Icr. woschmidti. Later on it appeared evident that other species, like Icr. hesperius, were more common and widespread than Icr. woschmidti, but in different schemes either one or the other species were used to name the first Devonian zone. Carls et al. (2007, pp. 158, 159) state that "the named taxon with wide distribution that appear closest to the lower Devonian system boundary is Icr. hesperius Klapper \& Murphy, 1975" and that Icr. woschmidti enters somewhere above within the lower Lochkovian. We agree that the best marker for this zone is Icr. hesperius (so the name), that is much more abundant than Icr. woschmidti; furthermore Icr. woschmidti occur only in the lower part of the zone.

We included in this zone also the postwoschmidti Zone of other schemes: the index taxon Icr. postwoschmidti is very rare in our sections, and therefore it looks not appropriate discriminate a zone after a taxon that in many sections has not been documented. However, since, when present, the species helps in the identification of the upper part of the zone and in other regions it is abundant, we indicate a "postwoschmidti subzone" in the upper part of the hesperius Zone.

The hesperius Zone, as we define here, includes the woschmidti-postwoschmidti and most of the eurekaensis Zone of the more recent scheme (Ogg et al. 2008). The eurekaensis zone cannot be discriminated outside a few North American regions, because the marker has a limited geographical distribution. Carls et al. (2007, p. 158) agree that "a succession of hesperius Zone and revised postwoschmidti Zone for the interval before Ancyrodelloides carlsi would be more appropriate".

Icr. woschmidi is limited to the lower part of the zone, and Sannemannia ichnusae to a short interval at the base of the postwoschmidti subzone. Pedavis biexoramus enters in the central part of the zone; Ozarkodina eosteinhornensis s.l. and Oulodus el. elegans have their last occurrence within the zone, just below the first occurrence of Pandorinellina repetitor and Icr. postwoschmidti.

\section{Carlsi Zone}

Lower limit. - First occurrence of Ancyrodelloides carlsi.

Upper limit. - First occurrence of Ancyrodelloides transitans.

Associated conodonts. - Ancyrodelloides carlsi (Boersma), Belodella anomalis Cooper, Belodella resima (Philip), Icriodus angustoides alcoleae Carls, Lanea eoeleanorae Murphy \& Valenzuela-Ríos, Lanea omoalpha Murphy \& 


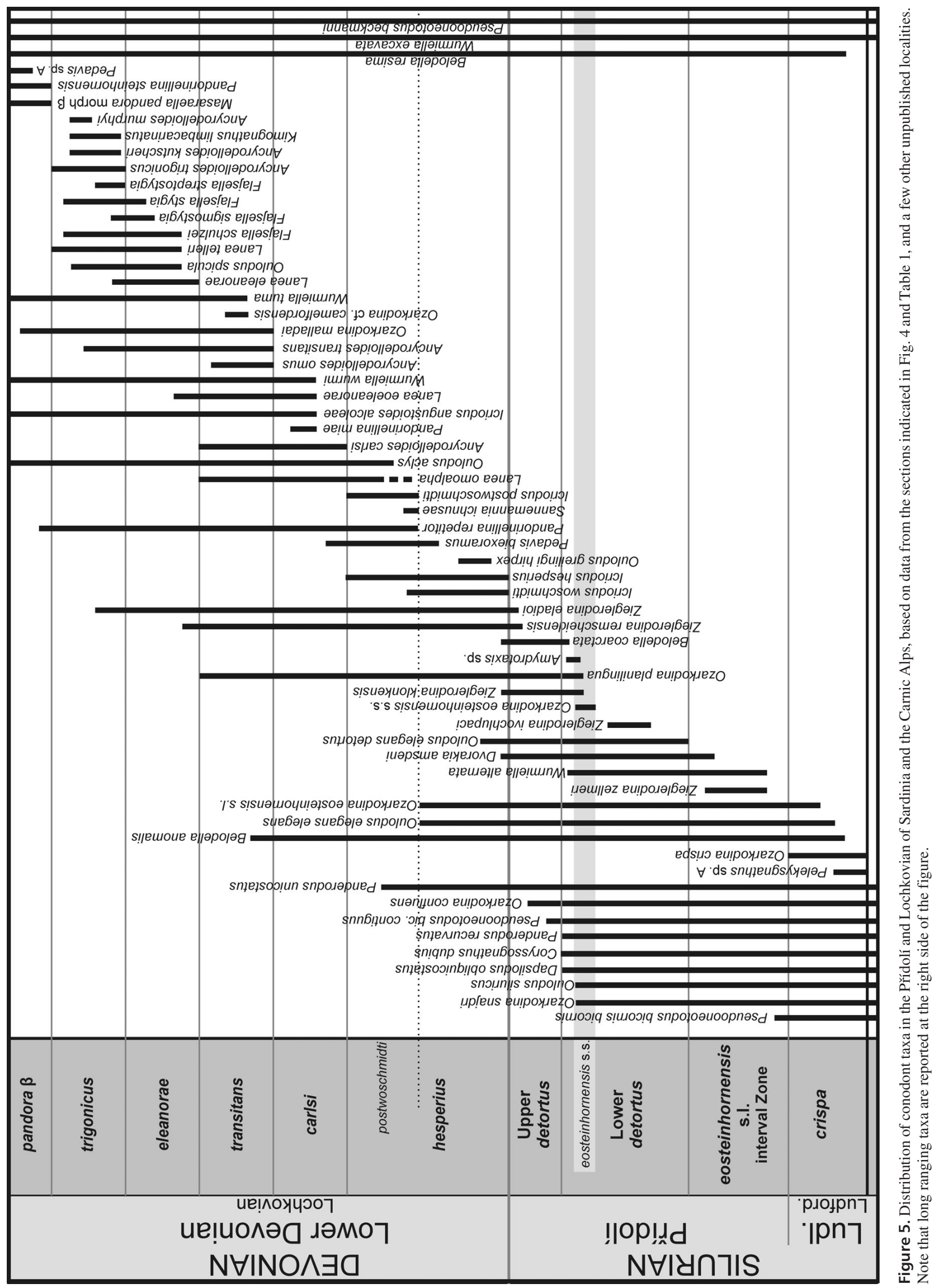


Valenzuela-Ríos, Oulodus aclys Mawson, Ozarkodina planilingua Murphy \& Valenzuela-Ríos, Pandorinellina miae (Bultynck), Pandorinellina repetitor Carls \& Gandl, Pedavis biexoramus Murphy \& Matti, Pseudooneotodus beckmanni (Bischoff \& Sannemann), Wurmiella excavata (Branson \& Mehl), Wurmiella wurmi (Bischoff \& Sannemann), Zieglerodina eladioi (Valenzuela-Ríos), Zieglerodina remscheidensis (Ziegler).

Remarks. - This zone is introduced herein. It corresponds to the upper part of the North American eurekaensis Zone and to the lower part of the delta Zone. In this respect it includes the omoalpha Zone by Murphy \& Valenzuela-Ríos (1999) because Lanea omoalpha occur in definitely lower stratigraphic levels in the Carnic Alps (i.e. Monte Cocco II and Costone Lambertenghi sections) and in Bohemia (M. Murphy, pers. comm., August 2011) and therefore its use as a marker should be re-evaluated after its stratigraphical distribution will be clarified.

The enter of Ancyrodelloides carlsi Zone can be used to define the base of the middle Lochkovian, as already suggested by Slavík (2011).

Valenzuela-Ríos (1994a) documented an "Intervalo carlsi + transiens" in the Lochkovian of the central Pyrenees, but this proposal was never considered in other regions and in more recent schemes. This is probably due to taxonomical problems between the species Ozarkodina carlsi Boersma and Oz. masara Schönlaub: Schönlaub (1980) described the species Oz. masara from the Carnic Alps and Bohemia, and several occurrences were referred to this taxon (i.e. Chlupáč 2000, Boncheva et al. 2007). However, as stated by Corriga (2011) and Slavík (2011), Oz. masara Schönlaub is a junior synonym of Ad. carlsi (Boersma). Recently, the species was attributed to the genus Lanea by Slavík (2011).

Beside the Carnic Alps and Northeastern Spain, the biozone can be recognized in several regions, where $\mathrm{Ad}$. carlsi is documented in the uppermost part of the former eurekaensis Zone and/or in the lower part of the delta Zone: Frankenwald (Bischoff \& Sannemann, 1958), Central Spain (Carls \& Gandl 1969), Spanish Pyrenees (Boersma 1973; Valenzuela-Ríos, 1990, 1994a), Bohemia (Chlupáč et al. 1980, Chlupáč 2000, Slavík 2011), Morocco (Lazreq \& Ouanaimi 1998), Bulgaria (Boncheva et al. 2007), Australia (Farrell 2003), and possibly Nevada (Murphy \& Matti 1983).

In Sardinia the carlsi Zone is not documented and the index taxon is missing: probably corresponds to the covered interval above the occurrence of Icriodus postwoschmidti in the Mason Porcus section.

Lanea eoeleanorae, Icr. angustoides alcoleae and Wurmiella wurmi enters within this zone, whereas Pedavis biexoramus became extinct it its lower part.

\section{Transitans Zone}

Lower limit. - First occurrence of Ancyrodelloides transitans.

Upper limit. - First occurrence of Lanea eleanorae.

Associated conodonts. - Ancyrodelloides carlsi (Boersma), Ancyrodelloides omus Murphy \& Matti, Ancyrodelloides transitans (Bischoff \& Sannemann), Belodella anomalis Cooper, Belodella resima (Philip), Icriodus angustoides alcoleae Carls, Lanea eoeleanorae Murphy \& Valenzuela-Ríos, Lanea omoalpha Murphy \& Valenzuela-Ríos, Oulodus aclys Mawson, Ozarkodina cf. camelfordensis Farrell, Ozarkodina malladai Valenzuela-Ríos, Ozarkodina planilingua Murphy \& Valenzuela-Ríos, Pandorinellina repetitor Carls \& Gandl, Pseudooneotodus beckmanni (Bischoff \& Sannemann), Wurmiella excavata (Branson \& Mehl), Wurmiella tuma (Murphy \& Matti), Wurmiella wurmi (Bischoff \& Sannemann), Zieglerodina eladioi (Valenzuela-Ríos), Zieglerodina remscheidensis (Ziegler).

Remarks. - This zone was introduced by Valenzuela-Ríos (1994a) in the Spanish Central Pyrenees, and later accepted by Murphy \& Valenzuela-Ríos (1999) in Nevada and the Spanish Pyrenees. It can be easily recognized in Sardinia and the Carnic Alps. It corresponds to an interval in the lower-central part of the delta Zone.

Ancyrodelloides omus, Ozarkodina malladai and $\mathrm{Oz}$. cf. camelfordensis are exclusive of this zone; Wurmiella tuma enters within the zone, and Lanea omoalpha became extinct in the upper part, and Ancyrodelloides carlsi and Ozarkodina planilingua at the top of the zone.

\section{Eleanorae Zone}

Lower limit. - First occurrence of Lanea eleanorae.

Upper limit. - First occurrence of Ancyrodelloides trigonicus.

Figure 6. Index fossils and other useful conodonts for the Př́dolí and Lochkovian biostratigraphy. • A - Panderodus recurvatus (Rhodes, 1953); MDLCA 30043, lateral view, Rifugio Lambertenghi Fontana section, sample RLF 2B. • B - Dapsilodus obliquicostatus (Branson \& Mehl, 1933); MDLCA 30034, lateral view, Rifugio Lambertenghi Fontana section, sample RLF 1. • C, D - Ozarkodina crispa (Walliser, 1964); IPUM 27677, lateral (C) and upper (D) views of P1 element, Monte Cocco II section, sample MC II 1. • E - Coryssognathus dubius (Rhodes, 1953); 


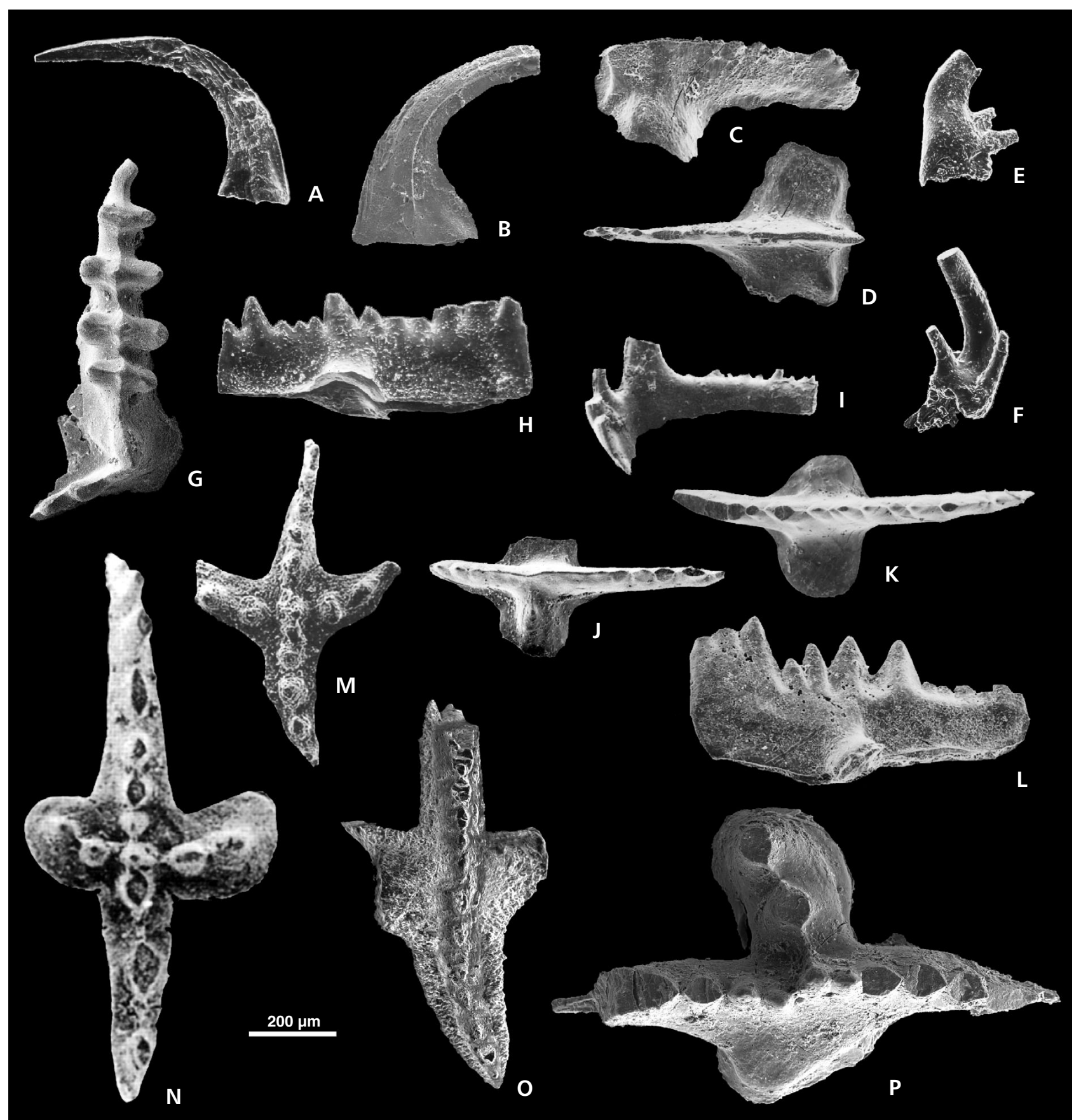

MDLCA 30035, lateral view of S2 element, Rifugio Lambertenghi Fontana III section, sample RLF III 2B. • F - Coryssognathus dubius (Rhodes, 1953); MDLCA 30038, lateral view of S0/S1 element, Rifugio Lambertenghi Fontana III section, sample RLF III 2B. • G - Icriodus hesperius Klapper \& Murphy, 1975; IPUM 28195, upper view of P1 element, Monte Cocco II section, sample MC II 5F. • H - Zieglerodina remscheidensis (Ziegler, 1960); MDLCA 30063, lateral view of P1 element, Rifugio Lambertenghi Fontana III section, RLF III 1X. • I - Oulodus elegans detortus (Walliser, 1964); IPUM 23457, lateral view of S2 element, Mason Porcus section, sample MP 11.• J - Ozarkodina eosteinhornensis s.s. (Walliser, 1964); IPUM 27673, upper view of P1 element, Monte Cocco II section, sample MC II 3D.・K - Ozarkodina eosteinhornensis s.1. (Walliser, 1964); IPUM 27672, upper view of P1 element, Monte Cocco II section, sample MC II 3D. • L - Ozarkodina confluens (Branson \& Mehl, 1933); IPUM 27681, lateral view of P1 element, Monte Cocco II section, sample MC II 4A. • M - Ancyrodelloides trigonicus Bischoff \& Sannemann, 1958; IPUM 20953 upper view of P1 element, Galemmu II section, sample GALE II G. • N - Ancyrodelloides transitans Bischoff \& Sannemann, 1958; upper view of P1 element, Galemmu II section, sample GALE II D. • O - Lanea eleanorae (Lane \& Ormiston, 1979); MDLCA 30128, upper view of P1 element, La Valute section, sample LV 2. • P - Ancyrodelloides carlsi (Boersma, 1973); MDLCA 30186, upper view of P1 element, Rio Malinfier section, sample RM 1. Repository of figured specimens: IPUM = Museo di Paleontologia, Università di Modena e Reggio Emilia; MDLCA = Museo Domenico Lovisato, Università di Cagliari. 
Associated conodonts. - Ancyrodelloides transitans (Bischoff \& Sannemann), Belodella resima (Philip), Flajsella schulzei (Bardashev), Flajsella sigmostygia Valenzuela-Ríos \& Murphy, Flajsella stygia (Flajs), Icriodus angustoides alcolae Carls, Lanea eleanorae Murphy \& Valenzuela-Ríos, Lanea eoeleanorae Murphy \& Valenzuela-Ríos, Lanea telleri (Schulze), Oulodus aclys Mawson, Oulodus spicula Mawson, Ozarkodina malladai Valenzuela-Ríos, Pandorinellina repetitor Carls \& Gandl, Pseudooneotodus beckmanni (Bischoff \& Sannemann), Wurmiella excavata (Branson \& Mehl), Wurmiella tuma (Murphy \& Matti), Wurmiella wurmi (Bischoff \& Sannemann), Zieglerodina eladioi (Valenzuela-Ríos), Zieglerodina remscheidensis (Ziegler).

Remarks. - This zone was introduced by Murphy \& Valenzuela-Ríos (1999) in Nevada and in the Spanish Central Pyrenees and can be recognized in Sardinia and the Carnic Alps. It corresponds to an interval in the central-upper part of the delta Zone.

Lanea telleri and Flajsella schulzei enters in the lower part of the zone, whereas other species of Flajsella ( $F l$. stygia and $F l$. sigmostygia) have their first occurrence one following the others.

Zieglerodina remscheidensis and Lanea eoeleanorae have their last occurrence within the zone.

\section{Trigonicus Zone}

Lower limit. - First occurrence of Ancyrodelloides trigonicus.

Upper limit. - First occurrence of Masaraella pandora morph $\beta$.

Associated conodonts. - Ancyrodelloides kutscheri (Bischoff \& Sannemann), Ancyrodelloides murphyi Valenzuela-Ríos, Ancyrodelloides transitans (Bischoff \& Sannemann), Ancyrodelloides trigonicus (Bischoff \& Sannemann), Belodella resima (Philip), Flajsella schulzei (Bardashev), Flajsella sigmostygia Valenzuela-Ríos \& Murphy, Flajsella streptostygia Valenzuela-Ríos \& Murphy, Flajsella stygia (Flajs), Icriodus angustoides alcoleae Carls, Kimognathus limbacarinatus (Murphy \& Matti), Lanea eleanorae Murphy \& Valenzuela-Ríos, Oulodus aclys Mawson, Oulodus spicula Mawson, Ozarkodina malladai Valenzuela-Ríos, Pandorinellina repetitor Carls \& Gandl, Pseudooneotodus beckmanni (Bischoff \& Sannemann), Wurmiella excavata (Branson \& Mehl), Wurmiella tuma (Murphy \& Matti), Wurmiella wurmi (Bischoff \& Sannemann), Zieglerodina eladioi (Valenzuela-Ríos).

Remarks. - This zone was introduced by Valenzuela-Ríos (1994a) in the Spanish Central Pyrenees, and later accepted by Murphy \& Valenzuela-Ríos (1999) in Nevada and the
Spanish Pyrenees. It can be easily recognized in Sardinia and the Carnic Alps. It corresponds to the upper part of the delta Zone and is the last middle Lochkovian zone.

The marker Ancyrodelloides trigonicus is exclusive of this zone, Flajsella streptostygia is present only in the lower part, and Ancyrodelloides kutscheri and Ad. murphyi occur in the central part of the zone. All the species of genus Flajsella became extinct within this zone, and Lanea telleri has its last occurrence in its uppermost part.

\section{Pandora $\beta$ Zone}

Lower limit. - First occurrence of Masaraella pandora morph $\beta$.

Associated conodonts. - Belodella resima (Philip), Icriodus angustoides alcoleae Carls, Masaraella pandora morph $\beta$ Murphy et al., Oulodus aclys Mawson, Ozarkodina malladai Valenzuela-Ríos, Pandorinellina repetitor (Carls \& Gandl), Pandorinellina steinhornensis Ziegler, Pedavis sp. A Corriga et al., Pseudooneotodus beckmanni (Bischoff \& Sannemann), Wurmiella excavata (Branson \& Mehl), Wurmiella tuma (Murphy \& Matti), Wurmiella wurmi (Bischoff \& Sannemann).

Remarks. - This zone was introduced by Valenzuela-Ríos (1994a) in the Spanish Central Pyrenees, and later accepted by Murphy \& Valenzuela-Ríos (1999) also in Nevada. It corresponds to part of the pesavis Zone of several zonation schemes. We prefer use Masaraella pandora morph $\beta$ as index, because this taxon is more abundant and easy recognizable than species of Pedavis. Furthermore, doubt on the opportunity of naming a zone after $\mathrm{Pe}$. pesavis were discussed by other authors (i.e. Valenzuela-Ríos 1994b). This zone marks the base of the upper Lochkovian according to Valenzuela-Ríos \& Murphy (1997), even if in this subdivision the upper Lochkovian is definitely much shorter that the lower and middle part of the stage.

In our sections the pandora $\beta$ Zone is documented only in the Mason Porcus and La Valute section, where its upper boundary is not exposed. Therefore it is not possible to stress more comments.

\section{Discussion and comparison with other areas}

It is difficult comparing a regional zonation scheme with data from other geographic areas for several reasons. The main problem is related to taxonomical attributions of fauna by different authors: in the case of well established species (i.e. Polygnathoides siluricus) there are no problems; but it is almost impossible to know the range of recent 
species, even more if not all the scientific community accept these new proposal. As example we can consider the recent revision of late Silurian and earliest Devonian Ozarkodinids: Murphy et al. (2004) splitted the genus Ozarkodina Branson \& Mehl, 1933 into several new genera (Wurmiella, Zieglerodina and another one not established according to the ICZN code), restricting the diagnosis of Ozarkodina on the basis of Oz. confluens Branson \& Mehl, 1933 (= Oz. typica sensu Murphy et al., 2004); later on, the same group of authors (Carls et al. 2005) introduced genus Parazieglerodina, that in our opinion is questionable because it is to much similar to Zieglerodina. However, not all the species that previously belong to Ozarkodina have a home in this scenario. Moreover, Murphy et al. (2004) restricted the diagnosis of $Z$. remscheidensis to morphs similar to the holotype of Ziegler (1960, pl. 13, fig. 4) and Carls et al. (2007) introduced three new species, but several other possible species of Zieglerodina (before named as $\mathrm{Oz}$. remscheidensis) are still to be described; to make things even more difficult, these authors provided only very limited synonymy lists. As a result, this partial revision generate several problems: some scientists do not accept this approach and still refer all these species to Oz. remscheidensis (i.e. Suttner 2007) or more generally to a "remscheidensis Group" (i.e. Kleffner et al. 2009). This different approaches create a lot of confusion, that will be solved when the taxonomic revision will be completed. As for now it is impossible knowing the precise range of various taxa from literature and refer to a well established zonation scheme.

Our newly introduced zones (Lower and Upper detortus, and carlsi zones) can be recognized also in other regions:

- the lower boundary of the Upper detortus Zone can be recognized in the central-south United States, where Barrick et al. (2005) and Jacobi et al. (2009) documented a simultaneous extinction of several coniform species in the late Př́idolí, including Dapsilodus obliquicostatus. The range of Coryssognathus in the Frankenwald (Carls et al. 2007) allows recognition of this zone. Lack of information on distribution of coniform conodonts in other regions prevents any further comment.

- an interval characterized by Ancyrodelloides carlsi between the hesperius and the transitans zones may be recognized in several european regions (Germany, Central Spain, Spanish Central Pyrenees, Bohemia, Bulgaria), in North Africa (Morocco), Australia, and possibly North America.

\section{The eosteinhornensis s.s. horizon}

Another important correlation point is the Ozarkodina eosteinhornensis s.s. horizon, occurring in the upper part of the Lower detortus Zone. The name Ozarkodina eostein- hornensis s.s. is widely used in literature to indicate the morphotype similar to the holotype designed by Walliser (1964), characterized by a denticle or a small ridge above one side of the basal cavity. These forms have also been referred to morph $\beta$ by Olivieri \& Serpagli (1990) and to morph $\alpha$ by Murphy et al. (2004). Murphy et al. (2004) proposed a new genus ("Genus W") to represent the "eosteinhornensis group", but their proposal in not valid according to the ICZN code, and therefore it cannot be accepted.

Beside problems of nomenclature, Ozarkodina eosteinhornensis s.s. is well known in several North Gondwana regions (Bohemia, the Carnic Alps, Frankenwald, Sardinia) and characterizes a very short interval in the upper Přídolí. However, even if the eosteinhornensis s.s. horizon is very useful for correlations, it looks not appropriate naming a zone after it, because the conodont association immediately below and above this horizon is very similar: in case it have not been sampled, being somewhere reduced to a few centimeters of rock, it is not possible to distinguish the correct biostratigraphic position of a sample, if just below or just above the eosteinhornensis s.s. horizon, in the upper part of the Lower detortus Zone.

\section{The subdivision of the delta Zone}

In the more recent mid-Lochkovian zonation Murphy \& Valenzuela-Ríos (1999) subdivided the delta Zone into four zones (omoalpha, transitans, eleanorae and trigonicus), on the basis of the conodont distribution in Nevada and Spain. This subdivision works well also in the Carnic Alps and in Sardinia, and the last three zones are accepted. Some problems arose with the omoalpha Zone, that we included in the carlsi Zone. In fact L. omoalpha is present in older levels in some localities: in the Monte Cocco II section (Corriga \& Corradini 2009) it occurs together with Icr. hesperius and Ped. biexoramus, that is in the upper part of the hesperius Zone, and in the Costone Lambertenghi section have been found in the lower Lochkovian, well below the entry of Ad. carlsi. Similar early occurrence is documented in Bohemia (M. Murphy, pers. comm., August 2011); also in Bohemia, Slavík (2011, fig. 2) reports a "pre-Lanea" with incipient terraces and a Lanea cf. omoalpha from the lower Lochkovian. Therefore, it is better not to use L. omoalpha as a zonal marker until its taxonomic characterization will be done, and its stratigraphic range will be clear. On the other hand, Ad. carlsi is a good marker, widespread and relatively abundant and its range starts only slightly below the base of the former delta Zone, and, therefore, the carlsi Zone is a better biostratigraphic unit than the omoalpha Zone sensu Murphy \& Valenzuela-Ríos (1999). Furthermore, as suggested by Slavík (2011), the FAD of Ad. carlsi can be a good marker for the base of the middle Lochkovian. 


\section{Comments on recognizing the Silurian/Devonian boundary by conodonts}

A precise recognition of the Silurian/Devonian boundary on the basis of conodonts has always been a problem. In fact, the boundary is defined by the First Appearance Datum of the graptolite Monograptus uniformis, and it is not clear if any conodont species has a simultaneous first occurrence. The hesperius Zone is considered the first Devonian conodont zone. For long time this zone have been named woschmidti Zone because all the earliest Lochkovian representatives of genus Icriodus were attributed to Icr. woschmidti (Carls et al. 2007). As pointed out above, taxonomic revisions suggest that it is better naming this zone after Icr. hesperius, because it is "the named taxon with wide distribution that appears closest to the lower Devonian boundary" (Carls et al. 2007, pp. 157, 158).

The occurrence of Icriodus can be considered a proof of Devonian age. However, according to Jeppsson (1988), in many sections, I. woschmidti occurs slightly before M. uniformis, but this fact may be due to facies control: in fact graptolites are normally collected from shales and conodonts from limestones. Furthermore, icriodids are typical of inshore shallow water deposits (Bultynck 2003), whereas are rare in other marine environments. As a result, Icriodus is very rare, if not absent, in many sections.

In our sections in the Carnic Alps and Sardinia some datum points have been observed just below or above the first occurrence of Icriodus and can help to approximate the Silurian/Devonian boundary position:

1. Ozarkodina confluens has its last occurrence in the latest Přídolí (upper part of the Upper detortus Zone), immediately followed by

2. the first occurrence of Zieglerodina remscheidensis and Zieglerodina eladioi and

3. the first occurrence of Icriodus hesperius and Icriodus woschmidti (base of the Devonian). In a few sections (i.e: Monte Cocco II) the two species enters together, whereas elsewhere (i.e. Mason Porcus) Icr. hesperius has a slightly older first occurrence.

4. Belodella coarctata, Dvorakia amsdeni and Zieglerodina klonkensis have their last occurrence just above the entry of icriodids.

\section{Conclusions}

Nine conodont zone have been discriminated in the Přídolí and Lochkovian of the Carnic Alps and Sardinia: eosteinhornensis s.l. interval Zone, Lower detortus and Upper detortus zones in the Přídolí, hesperius, carlsi, transitans, eleanorae, trigonicus and pandora $\beta$ zones in the Lochkovian.
The main differences with the schemes in use are:

1. In the Přídolí, the detortus Zone is subdivided into two parts, a Lower detortus Zone and an Upper detortus Zone;

2. In the Lochkovian the hesperius Zone (including the postwoschmidti subzone in the upper part) is expanded to include most of the eurekaensis Zone;

3. The carlsi Zone, here introduced, corresponds to the upper part of the eurekaensis Zone and to the lower part of the delta Zone (omoalpha Zone sensu Murphy \& Valenzuela-Ríos, 1999); the base of this zone is a good marker for the base of the middle Lochkovian, as already proposed by Slavík (2011);

4. The zonation proposed by Murphy \& ValenzuelaRíos (1999) to substitute the central and upper part of the delta Zone and the pesavis Zone is accepted: in this interval the transitans, eleanorae, trigonicus and pandora $\beta$ are discriminated.

\section{Acknowledgments}

We thank Mike Murphy (Riverside), Claudia Spalletta (Bologna), Peter Carls (Braunschweig), Thomas Suttner (Graz) and Ladislav Slavík (Prague) for discussions and useful suggestions. We are deeply grateful to Nacho Valenzuela-Ríos (Valencia) and Ladislav Slavík for critical revision of the manuscript. This study was partly supported by R.A.S. (grants LR7/2007 - resp. C. Corradini). This paper is a contribution to IGCP projects No. 591 - The Early to Middle Paleozoic Revolution, and 596 Climate change and biodiversity patterns in the Mid-Paleozoic.

\section{References}

AldRIDGe, R.J. \& SchÖNLAUb, H.P. 1989. Conodonts, 274-279. In Holland, C.H. \& Bassett, M.G. (eds) A Global Standard for the Silurian System. National Museum of Wales, Geological Series 9.

Barca, S., Corradini, C., Ferretti, A., Olivieri, R. \& Serpagli, E. 1995. Conodont biostratigraphy of the "Ockerkalk" (Silurian) from southeastern Sardinia. Rivista Italiana di Paleontologia e Stratigrafia 100(1994), 459-476.

Barrick, J.E., Meyer, B.D. \& Ruppel, S.C. 2005. The Silurian-Devonian boundary and the Klonk Event in the Frame Formation, subsurface West Texas, 105-122. In BARRICK, J.E. \& Lane, H.R. (eds) A standing ovation: Papers on honour of Gilbert Klapper. Bulletins of American Paleontology 369.

Bischoff, G. \& Sannemann, D. 1958. Unterdevonische Conodonten aus dem Frankenwald. Notizblatt des Hessischen Landesamtes für Bodenforschung 86, 87-110.

Boersma, K.T. 1973. Description of certain Lower Devonian platform conodonts of the Spanish Central Pyrenees. Leidse Geologische Mededelingen 49, 285-301.

Boncheva, I., Sachanski, V., Lakova, I. \& Yaneva, M. 2007. Facies transition and biostratigraphic correlation of the Upper 
Silurian and Lower Devonian in West Bulgaria. Geological Quarterly 51, 407-418.

Branson, E.B. \& Mehl, M.G. 1933. Conodonts from the Bainbridge Formation (Silurian) of Missouri. University of Missouri Studies 8, 39-52.

Bultynck, P. 2003. Devonian Icridontidae: biostratigraphy, classification and remarks on paleoecology and dispersal. Revista Española de Micropaleontología 35(3), 295-314.

CARls, P. 1969. Die Conodonten des tieferen Unter-Devons der Guadarrama (Mittel-Spanien) und die Stellung des Grenzbereisches Lochkovium/Pragium nach der rheinischen Gliederung. Senckenbergiana lethaea 50, 303-355.

CARLs, P. 1975. Zusätzliche Conodonten-Funde aus dem tieferen Unter-Devon Keltiberiens (Spanien). Senckenbergiana lethaea 56, 399-428.

Carls, P. \& Gandl, J. 1969. Stratigraphie und Conodonten des Unter-Devons der Östlischen Iberischen Ketten (NE Spanien). Neues Jahrbuch für Geologie und Paläontologie, Abhandlungen 132, 155-218.

Carls, P., Slavík, L. \& Valenzuela-Ríos, J.I. 2005. A new Ludlow (Late Silurian) Spathognathodontidae (Conodonta) from Bohemia with incipient alternating denticulation. Neues Jahrbuch für Geologie und Paläontologie, Monatshefte 9, 547-565.

Carls, P., Slavík, L. \& Valenzuela-Ríos, J.I. 2007. Revisions of conodont biostratigraphy across the Silurian-Devonian boundary. Bulletin of Geosciences 82(2), 145-164. DOI 10.3140/bull.geosci.2007.02.145

Chlupáč, I. 2000. The global stratotype section and point of the lower Pragian boundary. In Bultynck, P. (ed.) Subcommission on Devonian Stratigraphy - Recognition of Devonian series and stage boundaries in geological areas. Courier Forschungsinstitut Senckenberg 225, 9-15.

ChluPÁč, I., KŘiž, J. \& SchöNlaub, H.P. 1980. Silurian and Devonian conodont localities in the Barrandian, 147-180. In Schönlaub, H.P. (ed.) Second European Conodont Symposium (ECOS II), Guidebook, Abstracts. Abhandlungen der Geologischen Bundesaltstalt 35.

Corradini, C. \& Corriga, M.G. 2010. Silurian and lowermost Devonian conodonts from the Passo Volaia area (Carnic Alps, Italy). Bollettino della Società Paleontologica Italiana 49(3), 237-253.

Corradini, C., Ferretti, A., Corriga, M.G. \& Serpagli, E. 2009a. The reference section of the Sardinian Ockerkalk: the Silius Section. Rendiconti della Società Paleontologica Italiana 3(2), 209-216.

Corradini, C., Ferretti, A., Corriga, M.G. \& Serpagli, E. 2009b. Loboliths (crinoids) and conodont biostratigraphy of the Genna Ciuerciu Section (SE Sardinia). Rendiconti della Società Paleontologica Italiana 3(2), 217-224.

Corradini, C., Ferretti, A. \& Serpagli, E. 1998. An Early Devonian section near Fluminimaggiore (Galemmu), 168-174. In SerPagli, E. (ed.) Sardinia Field-trip Guide-book, ECOS VII. Giornale di Geologia 60, Spec. Issue.

Corradini, C., Ferretti, A. \& Štorch, P. (eds) 2009c. The Silurian of Sardinia. Rendiconti della Società Paleontologica Italiana 3(1), 1-170.

Corradini, C., Leone, F., Loi, A. \& Serpagli, E. 2001. Conodont stratigraphy of a highly tectonised Siluro-Devonian Section in the San Basilio area (SE Sardinia). Bollettino della Società Paleontologica Italiana 40, 315-323.
Corradini, C. \& Olivieri, R. 1997. Conodont biostratigraphy of some supplementary sections in the Sardinian "Ockerkalk" (Upper Silurian). Bollettino Museo regionale di Scienze Naturali di Torino 15(1), 89-100.

Corradini, C. \& Serpagli, E. 1998. A Late Llandovery-Pridoli (Silurian) conodont biozonation in Sardinia, 85-88. In SERPAGLI, E. (ed.) Sardinia Field-trip Guide-book, ECOS VII. Giornale di Geologia 60, Spec. Issue.

Corradini, C. \& Serpagli, E. 1999. A Silurian conodont biozonation from late Llandovery to end Pridoli in Sardinia (Italy). Bollettino della Società Paleontologica Italiana 37(2-3), 255-273.

Corradini, C. \& Serpagli, E. 2000. A new (standard?) Silurian conodont zonation. Silurian Times 8, 25-28.

Corriga, M.G. 2007. Contesto geologico e biostratigrafico del Siluriano-Devoniano di Perda S'Altari, Sardegna sudoccidentale. 101 pp. Master thesis, Università di Cagliari, Italy.

Corriga, M.G. 2011. Biostratigrafia a conodonti attorno al limite Siluriano-Devoniano in alcune aree del Nord Gondwana. 174 pp. Ph.D. thesis, Università di Cagliari, Italy.

Corriga, M.G. \& CorradinI, C. 2009. Upper Silurian and Lower Devonian conodonts from the Monte Cocco II section (Carnic Alps, Italy). Bulletin of Geosciences 84(1), 155-168. DOI 10.3140/bull.geosci.1112

Corriga, M.G., Corradini, C. \& Ferretti, A. 2009. Silurian conodonts from Sardinia: an overview. Rendiconti della Società Paleontologica Italiana 3, 95-107.

Corriga, M.G., Suttner, T.J., Kido, E., Corradini, C., PondRelli, M. \& Simonetto, L. 2011. The La Valute limestone-Findenig limestone transition in the La Valute Section (Lower Devonian, Carnic Alps, Italy). Gortania Geologia, Paleontologia, Paletnologia 32, 5-12.

Cramer, B.D., Brett, C.E., Melchin, M.J, Männik, P., KlefFner, M.A., McLaughlin, P.I., Loydell, D.K., Munnecke, A., Jeppsson, L., Corradini, C., Brunton, F.R. \& Saltzman, M.R. 2011. Revised correlation of Silurian Provincial series of North America with global and regional chronostratigraphic units and $\delta^{13} \mathrm{C}_{\text {carb }}$ chemostratigraphy. Lethaia 44, 185-202. DOI 10.1111/j.1502-3931.2010.00234.x.

FARRELL, J.R. 2003. Late Pridoli, Lochkovian and early Pragian conodont from the Gap area between Larras Lee and Eurimbla, central western NSW, Australia. Courier Forschungsinstitut Senckenberg 245, 107-181.

Ferretti, A., Corradini, C., Oggiano, G. \& ŠTorch, P. 2009. Silurian palaeogeography of northern Gondwana: where was Sardinia at that time? Rendiconti della Società Paleontologica Italiana 3(1), 67-76.

Gnoli, M., Kř́ǐž, J., Leone, F., Olivieri, R., Serpagli, E. \& S̆TORCH, P. 1990. Lithostratigraphic units and biostratigraphy of the Silurian and early Devonian of Southwest Sardinia. Bollettino della Società Paleontologica Italiana 29(1), 11-23.

Gnoli, M., Leone, F., Olivieri, R. \& SerPagli, E. 1988. The Mason Porcus Section as reference section for Uppermost Silurian-Lower Devonian in SW Sardinia. Bollettino della Società Paleontologica Italiana 27(3), 323-334.

Histon, K. \& Schönlaub, H.P. 1999. The Palaeozoic of the Southern Alps, 6-30. In Histon, K. (ed.) V International Symposium, Cephalopods - Present and Past, Carnic Alps Excursion Guidebook. Berichte der Geologisches Bundesanstalt 47. 
House, M.R. \& Gradstein, F.M. 2004. The Devonian Period, 202-221. In Gradstein, F., OgG, J. \& Smith, A. (eds) A Geologic Time Scale 2004. Cambridge University Press, Cambridge.

JACOBI, D.J., BARRICK, J.E., KLEFFNER, M.A. \& KARLSSON, H.R. 2009. Stable isotope chemostratigraphy and conodont biostratigraphy across the Silurian-Devonian boundary in southwestern Laurentia, 9-31. In Over, D.J. (ed.) Studies in Devonian Stratigraphy: Proceedings of the 2007 International meeting of the Subcommission on Devonian Stratigraphy and IGCP 499. Palaeontographica Americana 63.

JePpsson, L. 1988. Conodont biostratigraphy of the Silurian-Devonian boundary stratotype at Klonk, Czechoslovakia. Geologica et Palaeontologica 22, 21-31.

JePpSson, L. 1989. Latest Silurian conodonts from Klonk, Czechoslovakia. Geologica et Palaeontologica 23, 21-37.

KLAPPER, G. 1977. Lower and Middle Devonian conodont sequence in Central Nevada, 33-54. In MuRPHY, M.A., BERRY, W.B.N. \& SANDBERG, C.A. (eds) Western North America: Devonian. University of California, Riverside-Campus Museum Contribution 4.

KLAPPER, G. 1991. Genus Ancyrodelloides, 17. In ZiegLer, W. (ed.) Catalogue of conodonts, Volume V. Schweizerbart'sche Verlagsbuchhandlung, Stuttgart.

KlapPer, G. \& MurPhy, M.A. 1975. Silurian-Lower Devonian conodont sequence in the Roberts Mountains Formation of central Nevada. University of California Publications in Geological Sciences 111, 1-62.

KLAPPER, G. \& ZiegLeR, W. 1979. Devonian conodont biostratigraphy, 199-224. In House, M.R., SCRutTon, C.T. \& BASSETT, M.G. (eds) The Devonian System. Special Papers in Palaeontology 23.

KlefFner, M.A., Barrick, J.E., Ebert, J.R., Matteson, D.K. \& Karlsson, H.R. 2009. Conodont biostratigraphy, $\delta^{13} \mathrm{C}$ chemostratigraphy, and recognition of Silurian/Devonian boundary in the Cherry Valley, New York region of the Appalachian Basin, 57-73. In Over, D.J. (ed.) Conodont studies commemorating the $150^{\text {th }}$ anniversary of the first conodont paper (Pander, 1856) and the $40^{\text {th }}$ anniversary of the Pander Society. Palaeontographica Americana 62.

Lane, H.R. \& Ormiston, A.E. 1979. Siluro-Devonian biostratigraphy of the Salmontrout River area, east-central Alaska. Geologica et Palaeontologica 13, 39-96.

Lazreq, N. \& Ounaimi, H. 1998. Le Dèvonien Inférieur de Tizi-n-Tichka (Haut Atlas) et de Laàyoune (Tata, Anti Atlas, Maroc): nouvelles datations at implications paléogéographiques. Senckenbergiana lethaea $77,223-231$.

Mashkova, T.V. 1978. Drevneyshie konodontovye kompleksy Devona SSSR. Sovetskaya Geologiya 4, 3-14. [in Russian]

MastandREA, A. 1985. Early Devonian (Lochkovian) conodonts from southwestern Sardinia. Bollettino della Società Paleontologica Italiana 23(2), 240-258.

Murphy, M.A. \& MatTI, J.C. 1983. Lower Devonian conodonts (hesperius-kindlei Zones), Central Nevada. University of California Publications in Geological Sciences 123, 1-82.

Murphy, M.A. \& Valenzuela-Ríos, J.I. 1999. Lanea new genus, lineage of Early Devonian conodonts. Bollettino della Società Paleontologica Italiana 37, 321-334.

Murphy, M.A., Valenzuela-Ríos, J.I. \& Carls, P. 2004. On classification of Pridoli (Silurian) Lochkovian (Devonian)
Spathognathodontidae (Conodonts). University of California, Riverside Campus Museum, Contribution 6, 1-25.

Nowlan, G.S. 1995. Left Hand Column for Correlation Charts. Silurian Times 3, 7-8.

OGg, J.G., OGG, G. \& GradsteIn, F.M. 2008. The concise Geologic Time Scale. 177 pp. Cambridge University Press, Cambridge.

Olivieri, R. \& Serpagli, E. 1990. Late Silurian-Early Devonians conodonts from Mason Porcus section near Fluminimaggiore in Southwest Sardinia. Bollettino della Società Paleontologica Italiana 29(1), 59.

Rhodes, F.H.T. 1953. Some British lower Paleozoic faunas. Philosophical Transactions of the Royal Society of London, Series B 237, 261-334. DOI 10.1098/rstb.1953.0005

SCHÖNLAUB, H.P. 1980. Silurian and Devonian conodont localities in the Barrandian, 5-57. In SCHÖNLAUB, H.P. (ed.) Second European Conodont Symposium (ECOS II), Guidebook, Abstracts. Abhandlungen der Geologischen Bundesantstalt 35.

SCHÖNLAUB, H.P. 1997. The Silurian of Austria. Berichte der Geologischen Bundesantstalt 40, 20-41.

Schönlaub, H.P. \& Histon, K. 2000. The Palaeozoic Evolution of the Southern Alps. Mitteilungen der Österreichischen Geologischen Gesellshaft 92(1999), 15-34.

SLAVÍK, L. 2011. Lanea carlsi conodont apparatus reconstruction and its significance for subdivision of the Lochkovian. Acta Palaeontologica Polonica 56(2), 313-327.

DOI 10.4202/app.2009.0046

SutTNER, T.J. 2007. Conodont stratigraphy, facies-related distribution patterns and stable isotopes (carbon and oxygen) of the uppermost Silurian to Lower Devonian Seewarte section (Carnic Alps, Carinthia, Austria). Abhandlungen der Geologischen Bundesantstalt 59, 1-111.

VALENZUELA-Ríos, J.I. 1990. Lochkovian conodonts and stratigraphy at Gerrida de La Sal (Pyrenees). Courier Forschungsinstitut Senckenberg 118, 53-63.

VAlenZuela-Ríos, J.I. 1994a. Conodontos del Lochkoviense y Praguiense (Devónico Inferior) del Pirineo Central Español. Memorias del Museo Paleontologico de la Universidad de Zaragoza 5, 1-142.

Valenzuela-Ríos, J.I. 1994b. The Lower Devonian conodonts Pedavis pesavis and the pesavis Zone. Lethaia 27, 199-207. DOI 10.1111/j.1502-3931.1994.tb01409.x

Valenzuela-Ríos, J.I \& Murphy, M.A. 1997. A new zonation of middle Lochkovian (Lower Devonian) conodonts and evolution of Flajsella n. gen. (Conodonta). Geological Society of America, Special Paper 321, 131-144.

Walliser, O. 1964. Conodonten des Silurs. Abhandlungen des Hessischen Landesamtes für Bodenforschung zu Wiesbaden 41, 1-106.

WedDige, K. 1996. Devon-Korrelationstabelle. Senckenbergiana lethaea 76, 267-286.

WENZEL, B. 1997. Isotopenstratigraphische Untersuchnungen an silurischen Abfolgen und deren paläozeanographische Interpretazion. Erlanger geologischen Abhandlungen 129, 1-117.

ZIEGLER, W. 1960. Conodonten aus dem Reinischen Unterdevon (Gedinnium) des Remscheider Sattels (Rheinisches Schiefergebirge). Paläontologische Zeitschrift 34(2), 169-201.

ZIEGLER, W. 1979. Historical subdivisions of the Devonian, 23-47. In House, M.R., Scrutton, C.T. \& Bassett, M.G. (eds) The Devonian System. Special Papers in Palaeontology 23. 